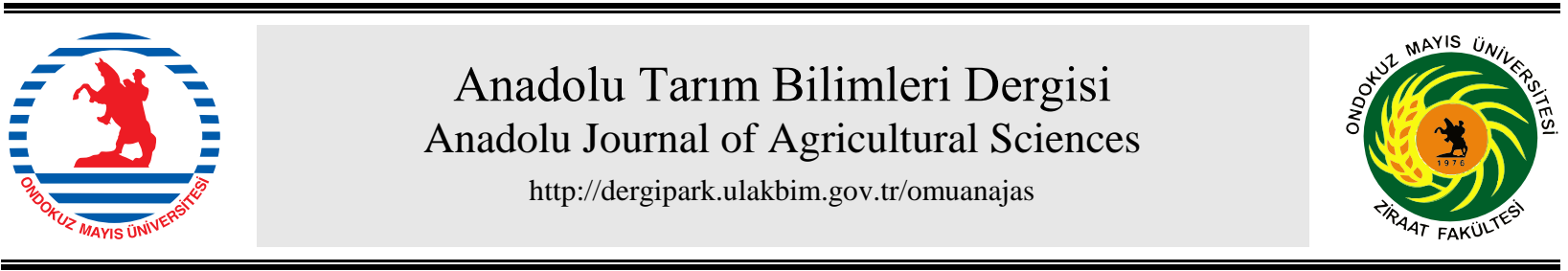

Research/Araştırma

Anadolu Tarım Bilim. Derg./Anadolu J Agr Sci, 31 (2016) ISSN: 1308-8750 (Print) 1308-8769 (Online) doi: 10.7161/omuanajas.269993

\title{
The effects of nuts per cluster and the fruit stem lengths on fruit detachment force/husky fruit weight ratio at different maturity times of hazelnut (cv. Yomra)
}

\author{
Taner Yildiz \\ Ondokuz Mayls University, Samsun Vocational School, Agricultural Machinery Program, Samsun, Türkiye \\ Sorumlu yazar/corresponding author: tyildiz@omu.edu.tr
}

Geliş/Received 14/07/2016 Kabul/Accepted 06/10/2016

\begin{abstract}
ÖZET
This study was conducted to determine the effects of nuts per cluster (NPC) and fruit stem lengths (FSL) on the fruit detachment force/husky hazelnut fruit weight (FDF/HFW) ratio in a hazelnut cultivar (Yomra cv.) at the different maturity times of fruit ripening (MTFR). In total, 63 hazelnut limbs allocated randomly into 21 experimental groups in a $3 \times 7$ factorial arrangements to evaluate the effect of maturity times of fruit ripening (MTFR), NPC and MTFR $\times$ NPC interaction on FSL, the fruit detachment force (FDF), husky fruit weight and FDF to $\mathrm{W}$ ratio. Three different maturity times of fruit ripening were determined for measurement the FSL, fruit detachment forces and husky hazelnut weights. The first maturity time was chosen as August $28^{\text {th }}$ which is indicating the approximately half of the matured hazelnuts (immediately at beginning of maturity, no delay, $\mathrm{IH}$ ). The second maturity time (September $\left.7^{\text {th }}\right)$ includes the term which nearly all the hazelnuts were matured $(10 \mathrm{~d}$ delay, 10DM). The natural fruit dropping time (September $15^{\text {th }}$ ) was evaluated as third maturity time (18 d delay, 18DM). NPC were classified as single, double, triple, four, five, six and seven nuts per cluster. The FDF of IH were higher $(\mathrm{P}=0.016)$ than that of $18 \mathrm{DM}$, while the FDF to $\mathrm{W}$ ratio of IH was higher $(\mathrm{P}<0.001)$ than that of $10 \mathrm{DM}$ and $18 \mathrm{DM}$. The increase in NPC was increased dramatically the FDF and HFW $(\mathrm{P}<0.001)$, but decreased the FDF to W ratio. The seven nuts per husky had higher FDF and HFW values compared to other NPC, whereas the single nut per cluster had lower the FDF and HFW values, and higher values the FDF to HFW ratio compared to triple, four, five and six nuts per cluster. The relationships between the NPC or FSL and other studied variables were significant. In conclusion, to delay the MTFR decreased the FDF and the increase in NPC improved the FDF and HFW and as a result decreased the FDF to W ratio in hazelnut Yomra cv. fruit detachment force, husky fruit weight, maturity time of fruit ripening
\end{abstract}

Farklı olgunlaşma dönemlerinde Yomra çeşidi findığın kopma kuvveti/zuruflu meyve ağırlı̆̆ı oranına, meyve sapı uzunlukları ve çotanak sayılarının etkileri

\begin{abstract}
$\mathrm{Bu}$ çalışma; farklı olgunlaşma dönemlerinde çotanaktaki fındık sayısının (ÇFS) ve meyve sapı uzunluklarının (MSU), fındıkta (Yomra çeşidi) meyve kopma kuvveti/zuruflu findık ağırlığı oranı (MKK/ZFA) üzerine etkilerinin belirlenmesi amacıyla yapılmıştır. Meyve olgunlaşma zamanı (MOZ), ÇFS ve MOZ x ÇFS etkileşiminin MSU, ZFA ve MSU/ZFA oranı üzerindeki etkisini değerlendirmek için 63 adet findık dalı 3 (olgunlaşma zamanı)x7 (çotanaktaki fındık sayısı) faktöriyel düzende olmak üzere 21 deneysel gruba rastgele ayrılmıştır. Meyve sapı uzunluklarının (MSU), meyve kopma kuvvetlerinin (MKK) ve zuruflu meyve ağırlıklarının (ZFA) ölçümü için üç farklı olgunlaşma dönemi belirlenmiştir. Birinci olgunlaşma dönemi, meyvelerin yaklaşık yarısının olgunlaştığı dönem (28 Ağustos 2010; olgunlaşmanın hemen başında, IH) olarak seçilmiştir. İkinci dönem, hemen hemen tüm findıkların olgunlaştığı dönemi (7 Eylül 2010, 10 gün sonra, 10H) içermektedir. Üçüncü olgunlaşma dönemi ise, findıkların doğal olarak yere dökülmeye başladığ 1 dönem olarak değerlendirilmiştir (15 Eylül 2010, 18 gün sonra, 18H). ÇFS ise tekli, ikili, üçlü, dörtlü, beşli, altılı ve yedili çotanak olarak sınıflandırılmıştır. Birinci olgunlaşma döneminde (IH) elde edilen meyve kopma kuvveti (MKK), üçüncü olgunlaşma döneminden $(18 \mathrm{H})$ daha yüksek $(P=0.016)$ bulunmuştur. Ayrıca, birinci olgunlaşma döneminde (IH) elde edilen meyve kopma kuvveti/zuruflu meyve ağırlığı (MKK/ZFA) oranı hem ikinci olgunlaşma dönemi $(10 \mathrm{H})$, hem de üçüncü olgunlaşma döneminden $(18 \mathrm{H})$ daha yüksek bulunmuştur $(\mathrm{P}<0.001)$. ÇFS'deki artış, hem MKK hem de ZFA değerlerini arttırmış ancak, MKK/ZFA oranını düşürmüştür $(\mathrm{P}<0.001)$. Yedili çotanak, diğer çotanaklar ile karşılaştırıldığında daha yüksek FKK ve ZFA oluştururken; tekli çotanak üçlü, dörtlü, beşli ve altılı çotanaklara göre bu parametreler bakımından daha düşük değerlere sahip olmuş ve daha yüksek MKK/ZFA oranı oluşturmuştur. ÇFS veya MSU ile diğer değişkenler arasındaki ilişkiler önemli bulunmuştur. Sonuç olarak; Yomra findık çeşidindeki MOZ gecikmesi, FKK değerini azaltırken; ÇFS artışı, FKK
\end{abstract} ve ZFA değerlerini iyileştirmiş ve sonuçta MKK/ZFA oranını düşürmüştür.

Anahtar Sözcükler:

Fruit removal

Fruit trees

Hazelnut

Mechanical

harvesting

Mechanical shakers

Shaking parameters

S 


\section{Giriş}

The hazelnut (Corylus avellana L.), one of the World's major nut crops is one of the most important agricultural products in Turkey. Also, hazelnut, which is one of the traditional export products of Turkey, provides foreign exchange input of nearly 1.5 billion dollar. Furthermore, this product, which is directly or indirectly related to livelihood of nearly 400.000 hazelnut producers, has an important place in Turkey economy (KIBGS, 2008; Aktaş et al., 2011; Yıldız ve Tekgüler, 2014).

Hazelnut is mainly cultivated in Black Sea Region of Turkey and it has been reported that almost 600.000 tons of hazelnut per year is produced on 432.439 ha in Turkey (TUIK, 2014). This amount is equal to nearly 70 $\%$ of total world hazelnut production. For harvesting this much of amount 306 labour unit hours (LUH) ha ${ }^{-1}$ are needed in Turkey. This amount stands for $71 \%$ of total working time and $55 \%$ of production costs. As usual the higher labour requirement increases the production costs, therefore, the labour costs must be decreased in hazelnut production. It is possible to decrease production costs by mechanization. In mechanical hazelnut harvesting, all of the fruits are dropped from the tree and then they are collected by picking machine (Beyhan and Yıldız, 1996; Yıldız, 2000). Hence, the percentage of fruit dropped from the tree is one of the important indicators of the efficiency of mechanical harvesting (Beyhan, 1996). The fruit removal is commonly achieved by vibrating the limbs or by shaking the trunk of the tree via mechanical shakers (Erdoğan, 1988; Erdoğan, 1990). Many researchers have studied on some parameters related to shakers frequency, amplitude, shaking time, shaking direction and limb connection height and those related to fruit detachment force/fruit weight (FDF/W) and the percentage of fruit removal on various fruits such as pistachio, citrus, hazelnut, olive, apricot, plum and almond with different operating principles of shakers (Polat et al., 2006; Polat et al., 2011; Farinelli et al., 2012; Yıldız and Tekgüler, 2014; Tekgüler et al., 2015). FDF/W is one of the most important factors in the mechanical harvesting of fruit trees.

Variation in the fruit detachment force to husky fruit weight $(\mathrm{FDF} / \mathrm{HFW})$ ratio is considered as one of the most important factors affecting efficiency of shaker in mechanical harvesting of hazelnut trees. In other words, $\mathrm{FDF} / \mathrm{HFW}$ ratio has a significant effect on rate of fruit removed from the limb by shaking. The FDF/HFW ratio decreases with increasing maturity time thus fruit falls to the ground easily (Erdoğan, 1988; Beyhan, 1996). However, there is not enough information about effects of FSL on FDF/W in mechanical harvesting of hazelnut. Accordingly, this study was conducted to determine the effects of nuts per cluster (NPC) may affects fruit stem lengths (FSL), FDF and FDF to $\mathrm{W}$ ratio increasing the effectiveness of the mechanical harvesting in a hazelnut cultivar (Yomra cv.).

\section{Materials and Methods}

Experiments were carried out in harvesting season of 2010 (from August to September), in a private farm in Emiryusuf village of Çarşamba town in Samsun, Turkey. Yomra variety was used as research material (Figure 1). Some characteristics of hazelnut Yomra cv. are given in Table 1.

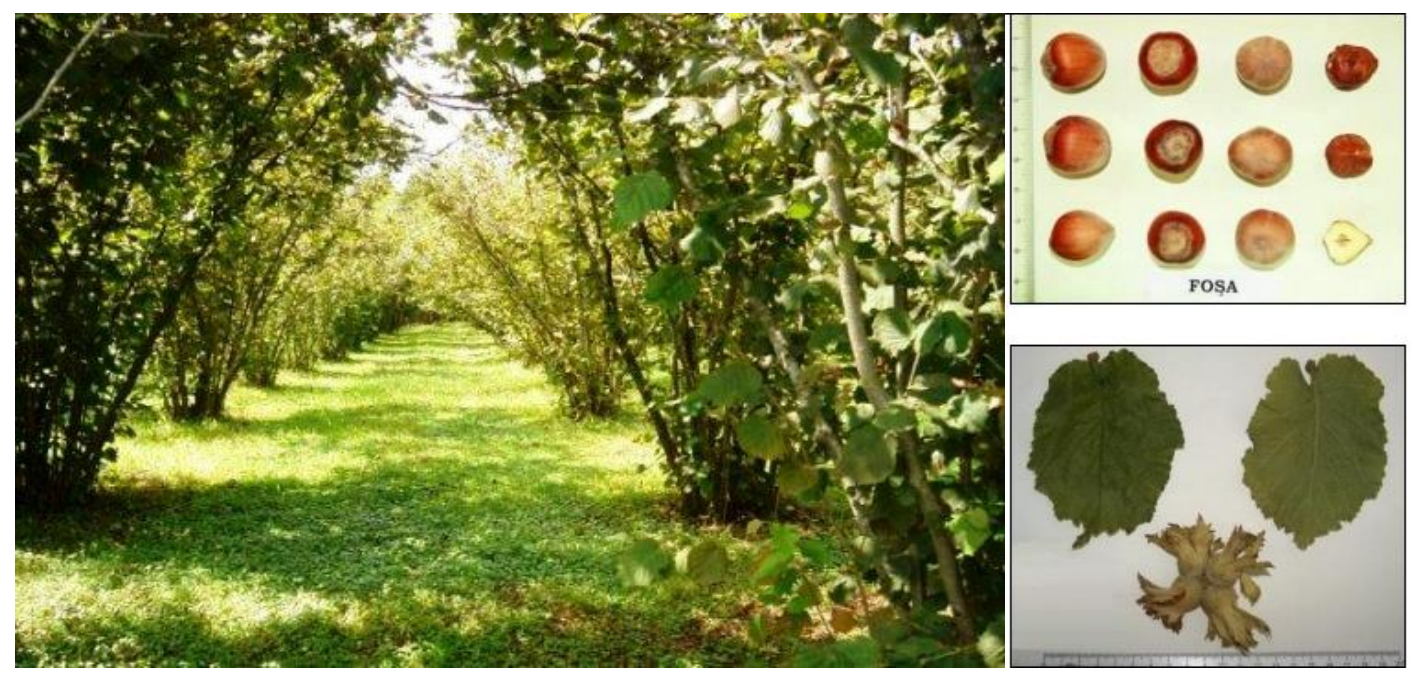

Figure 1. Hazelnut orchard, shelled and husky fruit

Three different maturity times of fruit ripening were determined for measurement the fruit stem lengths, fruit detachment forces and husky hazelnut weights. The first maturity time was chosen as August $28^{\text {th }}$ which is indicating the approximately half of the matured hazelnuts (immediately at beginning of maturity, no 
Table 1. Some characteristics of hazelnut Yomra cv. (Demir, 2004)

\begin{tabular}{lc}
\hline Nut length (mm) & $19.60 \pm 1.32$ \\
Nut width (mm) & $18.16 \pm 1.27$ \\
Nut depth (mm) & $17.06 \pm 1.36$ \\
Nut size (mm) & $18.22 \pm 0.97$ \\
Nut shape index & $1.12 \pm 0.11$ \\
Nut weight $(\mathrm{g})$ & $1.96 \pm 0.44$ \\
Kernel weight (g) & $1.10 \pm 0.26$ \\
Percent kernel (\%) & 51.61 \\
Good kernels (\%) & 77.34 \\
Shrivel kernels (\%) & 18.50 \\
Blank nuts (\%) & 2.84 \\
Double kernels (\%) & 0.00 \\
Moldy kernels (\%) & 1.34 \\
Shell thickness (mm) & $0.91 \pm 0.27$ \\
Husk length (mm) & $38.26 \pm 4.50$ \\
Nuts per cluster & $6.39 \pm 2.18$ \\
\hline
\end{tabular}

delay, IH). The second maturity time (September $7^{\text {th }}$ ) includes the term which nearly all the hazelnuts were matured (10 d delay, 10DM). The natural fruit dropping time (September $15^{\text {th }}$ ) was evaluated as third maturity time (18 d delay, 18DM). The husky hazelnuts were classified as single, double, triple, four, five, six and seven according to the number of nut, matured and representing the cultivars in husky. The FSL was measured by using digital callipers with a precision of $0.01 \mathrm{~mm}$. An electronic scale with a precision of $0.01 \mathrm{~g}$ was used for determining of the HFW. The pull force values were measured with a force gauge (MACRONA, capacity: $500 \mathrm{~N}$, resolution: $0.1 \mathrm{~N}$ ) for determining the FDF. Limbs were pulled perpendicular to their axes and then maximum pull forces were recorded (Beyhan, 1996; Gezer, 1999).

Analyses of variance were carried out using the General Linear Model (GLM) procedure of SPSS (IBM SPSS Statistics for Windows, Armonk, NY: IBM Corp) to evaluate the effect of maturity times of fruit ripening (MTFR), NPC and MTFR $\times$ NPC interaction on FSL, the fruit detachment force (FDF), fruit weight and FDF to HFW ratio in Yomra cv. Tree means were used as the experimental unit for all analyses. The significant differences were compared by using Tukey's range test. Differences between treatments were considered to be significant when $\mathrm{P}<0.05$ and tended to be significant when $0.05<\mathrm{P}<0.10$.

\section{Results and Discussion}

The FSL, FDF, HFW and FDF to HFW ratio of hazelnut with different NPC harvested mechanically at different MTFR are presented in Table 2.

The FDF of IH were higher $(P=0.016)$ than that of 18DM, while the FDF to HFW ratio of IH was higher $(\mathrm{P}<0.001)$ than that of $10 \mathrm{DM}$ and $18 \mathrm{DM}$. The increase in NPC was increased dramatically the FDF and HFW $(\mathrm{P}<0.001)$, but decreased the FDF to HFW ratio. The seven nuts per husky had higher FDF and HFW values compared to other NPC, whereas the single nut per cluster had lower the FDF and HFW values, and higher values the FDF to HFW ratio compared to triple, four, five and six nuts per cluster.

Estimated parameters for the regression equations of the NPC or FSL and FSL, FDF, HFW and FDF to HFW ratio, and bivariate correlations displaying the relationship among these variables and the NPC or FSL are presented in Table 3 .

The relationships between the NPC or FSL and other studied variables were significant. The present study was conducted as a first effort to determine the relationship between the NPC, FSL, FDF and FDF to HFW ratio, in order to improve the effectiveness of the mechanical harvesting with respect to harvesting technique in hazelnut (Yomra cv.).

There is not enough literature about FDF/W and FSL relationship. Torregrosa et al. (2014), conducted a research to determine the effect of peduncle length on the detachment of citrus fruits and observed that longer the stem, lower the detachment. However, Kouraba et al. (2004), reported that ripen table olives had higher fruit detachment force than the other ones. In other study, FDF/W ratios were determined 25 and 35 for ripe and unripe date palm fruits, respectively (Loghavi and Abounajmi, 2001). Safdari et al. (2010) indicated that the FDF/W ratio decreases at higher maturity periods for almond tree at eastern Azerbaijan province in Iran. Also, some comparisons with other studies performed on the other fruits such as plum, olive, pistachio, orange, dried fig, raspberry and coffee etc. similarly revealed that the FDF/W reduced as the maturity increased. (Polat, 1999; Pozo et al., 2007; Civil, 2009; Rabcewicz and Danek, 2010; Polat et al., 2011; Khorsandi et al., 2012; Yousefi and Gholiyan, 2013; Villibor et al., 2016). Bora et al. (2007) reported that fruit detachment force was lower for heavier oranges and the force required for the fruit detachment as the fruit (orange) ripens. Mailer et al. (2005) emphasized that fruits dropped sharply when reached full ripeness in olives. Segovia-Bravo et al. (2011) reported that unripe table olives had a high fruit removal force (FRF) and bruised easily. Similarly, Aslantas et al. (2016) indicated that the FDF/W ratio of sour cherry (Prunus cerasus L. cv. 'Kütahya') decreased as the fruit maturity increased.

Changes in the FDF/W ratios, due to different maturity times of fruit ripening and with nuts per cluster in Yomra hazelnut cultivar determined by following equation, were given in Figure 2.

$$
\mathrm{FDF} / \mathrm{W}=3.322 \times \mathrm{MTFR}^{-0.254} \times \mathrm{NPC}^{-0.571}
$$

As seen the Figure 2, FDF/W ratios were changed within large limits. Increases in MTFR and NPC decreased the average FDF/W ratios. However, this reduction was statistically significant between $10 \mathrm{DM}$ and $18 \mathrm{DM}$ with $\mathrm{IH}(\mathrm{P}<0.05)$. The findings in this study 
Table 2. Fruit stem lengths (FSL), fruit detachment force (FDF), fruit weight (HFW) and FDF to HFW ratio of hazelnut with different nuts per cluster (NPC) at different maturity times of fruit ripening (MTFR)

\begin{tabular}{|c|c|c|c|c|c|}
\hline MTFR & NPC, Nuts per cluster & FSL, mm & FDF, N & $\mathrm{HFW}, \mathrm{g}$ & FDF/HFW \\
\hline \multirow{7}{*}{$\mathrm{IH}$} & Single & 12.51 & 13.90 & 4.16 & 3.34 \\
\hline & Double & 13.12 & 12.87 & 5.24 & 2.45 \\
\hline & Triple & 14.68 & 20.63 & 11.85 & 1.86 \\
\hline & Four & 12.49 & 18.19 & 12.85 & 1.42 \\
\hline & Five & 13.05 & 21.40 & 17.50 & 1.22 \\
\hline & Six & 15.49 & 22.25 & 21.63 & 1.03 \\
\hline & Seven & 18.97 & 27.47 & 29.71 & 0.92 \\
\hline \multirow{7}{*}{$10 \mathrm{DM}$} & Single & 13.07 & 10.93 & 3.96 & 2.75 \\
\hline & Double & 13.75 & 12.74 & 7.77 & 1.76 \\
\hline & Triple & 16.90 & 14.11 & 9.40 & 1.52 \\
\hline & Four & 13.56 & 17.95 & 12.90 & 1.39 \\
\hline & Five & 16.71 & 19.71 & 17.09 & 1.16 \\
\hline & Six & 15.50 & 25.32 & 25.46 & 1.00 \\
\hline & Seven & 19.34 & 26.61 & 30.05 & 0.89 \\
\hline \multirow{7}{*}{$18 \mathrm{DM}$} & Single & 12.38 & 10.90 & 4.47 & 2.44 \\
\hline & Double & 17.91 & 12.38 & 8.16 & 1.52 \\
\hline & Triple & 13.16 & 13.41 & 9.46 & 1.49 \\
\hline & Four & 17.09 & 19.38 & 14.89 & 1.33 \\
\hline & Five & 14.54 & 19.89 & 17.39 & 1.14 \\
\hline & Six & 15.84 & 19.11 & 23.57 & 0.81 \\
\hline & Seven & 18.29 & 25.99 & 30.13 & 0.86 \\
\hline \multirow{3}{*}{ MTFR } & $\mathrm{IH}$ & 14.33 & $19.53 \mathrm{a}$ & 14.71 & $1.75 \mathrm{a}$ \\
\hline & $10 \mathrm{DM}$ & 15.55 & $18.20 \mathrm{ab}$ & 15.23 & $1.50 \mathrm{~b}$ \\
\hline & $18 \mathrm{DM}$ & 15.60 & $17.29 b$ & 15.44 & $1.37 \mathrm{~b}$ \\
\hline \multirow{7}{*}{ NPC } & Single & $12.65 \mathrm{c}$ & $11.91 \mathrm{e}$ & $4.20 \mathrm{~g}$ & $2.84 a$ \\
\hline & Double & $14.93 \mathrm{bc}$ & $12.66 \mathrm{e}$ & $7.06 \mathrm{f}$ & $1.91 \mathrm{~b}$ \\
\hline & Triple & $14.91 \mathrm{bc}$ & $16.05 \mathrm{~d}$ & $10.24 \mathrm{e}$ & $1.62 b$ \\
\hline & Four & $14.38 \mathrm{bc}$ & $18.51 \mathrm{c}$ & $13.55 \mathrm{~d}$ & $1.38 \mathrm{bc}$ \\
\hline & Five & $14.77 \mathrm{bc}$ & $20.33 b c$ & $17.33 \mathrm{c}$ & $1.17 \mathrm{~cd}$ \\
\hline & Six & $15.61 \mathrm{~b}$ & $22.23 b$ & $23.56 \mathrm{~b}$ & $0.95 \mathrm{~d}$ \\
\hline & Seven & $18.87 \mathrm{a}$ & $26.69 \mathrm{a}$ & $29.96 \mathrm{a}$ & $0.89 \mathrm{~d}$ \\
\hline $\begin{array}{l}\text { SEM (Standart error } \\
\text { of the mean) }\end{array}$ & & 0.291 & 0.304 & 0.270 & 0.036 \\
\hline \multicolumn{6}{|l|}{ Main effect of } \\
\hline MTFR & & 0.145 & 0.016 & 0.528 & $<0.001$ \\
\hline NPC & & $<0.001$ & $<0.001$ & $<0.001$ & $<0.001$ \\
\hline MTFRxNPC & & 0.153 & 0.068 & 0.516 & 0.159 \\
\hline
\end{tabular}

a,b,c means with different letters in the same column are different $(\mathrm{P}<0.05)$.

IH: immediately harvesting at beginning (August 28, 2010) of maturity, 10DM: $10 \mathrm{~d}$ delay (September 7, 2010) in maturity; 18DM: 18 d delay (September 15, 2010) in maturity. 
Table 3. Estimated parameters for the regression equations of the fruit stem lengths (FSL), fruit detachment force (FDF) and fruit weight (HFW) of hazelnut with nuts per cluster (NPC) at different maturity times of fruit ripening (MTFR) and bivariate correlations displaying the relationship among these variables and FSL or NPC

\begin{tabular}{lccccrl}
\hline Predictors & $\mathrm{a}$ & $\mathrm{SE}^{\S}$ & $\mathrm{b}$ & $\mathrm{SE}^{\dagger}$ & $\mathrm{t}$ & $\mathrm{r}$ \\
\hline Dependent variable: NPC & & & & & & \\
$\quad$ FSL & -1.072 & 1.185 & 0.335 & 0.077 & $4.358^{* * *}$ & $0.487^{* * *}$ \\
$\quad$ FDF & -1.776 & 0.432 & 0.315 & 0.023 & $13.979^{* * *}$ & $0.873^{* * *}$ \\
$\quad$ HFW & 0.680 & 0.145 & 0.219 & 0.008 & $26.517^{* * *}$ & $0.959^{* *}$ \\
Dependent variable: FSL & & & & & & \\
$\quad$ FDF & 10.471 & 1.126 & 0.256 & 0.059 & $4.349^{* * *}$ & $0.487^{* *}$ \\
HFW & 12.365 & 0.620 & 0.185 & 0.036 & $5.201^{* * *}$ & $0.554^{* * *}$ \\
\hline
\end{tabular}

$a$ : the intercept of the linear regression; SE $\$$ : standard error of the estimate,

$b$ : the relative growth or regression coefficient; $\mathrm{SE} \uparrow$ : standard error of the regression coefficient,

$* * P<0.01 ; * * * P<0.001$.

FDF $/ \mathrm{W}=3.322 \times \mathrm{MTFR}^{-0.254} \times \mathrm{NHH}^{-0.571}$

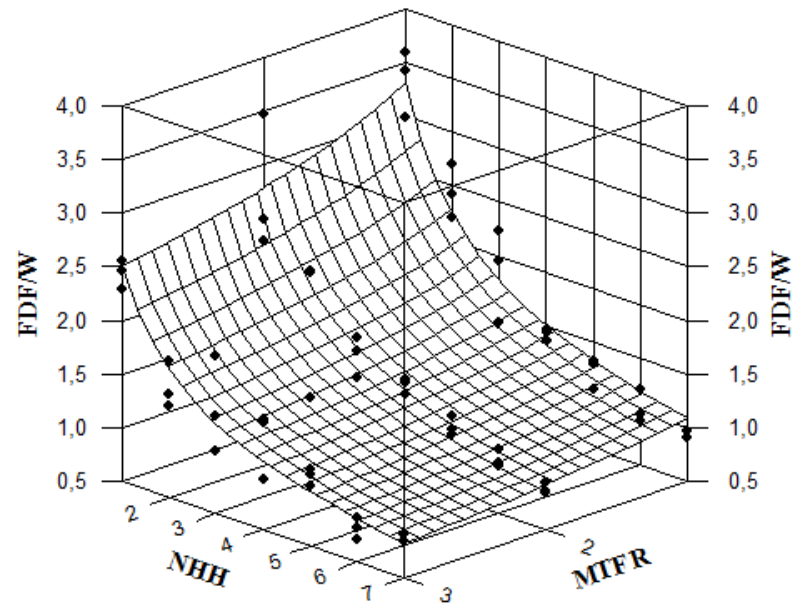

Figure 2. Changes in the FDF/W ratios, due to different MTFR and with NPC

to determine the relationship between the ripening period with FDF is similar to findings obtained in other studies. This finding is confirmed by studies conducted with other some fruit trees (Keçecioğlu, 1975; Beyhan, 1996; Gezer, 1999; Polat et al., 2011).

The results of this study revealed that: 1 . Fruit stem lengths (FSL) of the husky hazelnuts were not efficient on the FDF/HFW. 2. The FDF was found higher at IH than that of 10DM and 18DM. 3. The increase in NPC was increased the FDF and HFW but decreased the FDF to $\mathrm{W}$ ratio. 4 . The seven nuts per husky had higher FDF and HFW values compared to other NPC. 5. The relationships between the NPC or FSL and other studied variables were significant. In conclusion, to delay the MTFR decreased the FDF and the increase in NPC accelerated the FDF and HFW and as a result decreased the FDF to $\mathrm{W}$ ratio in hazelnut Yomra cv. It was determined that the FDF declines steadily as fruit ripens in this study.

\section{References}

Aktaş, A.R., Öztürk, E., Hatırlı, S.A., 2011. Türkiye fındık tarımında kar etkinsizliğinin analizi (Analysis of Profit Inefficiencies in Turkish Hazelnut Agriculture).Tarım Bilimleri Dergisi, 17: 230-240.

Aslantas R., Angin I., Boydas M.G., Ozkan, G., Kara, M., 2016. Fruit characteristics and detachment parameters of sour cherry (Prunus cerasus L. cv. 'Kütahya') as affected by various maturity stages. Erwerbs-Obstbau, 58(2):127-134.

Beyhan, M.A., 1996. Fındığın mekanik hasadında eksantrik tipli dal silkeleyicinin kullanılabilme olanağının belirlenmesi. Ondokuz Mayıs Üniversitesi Ziraat Fakültesi, Fındık ve Diğer Sert Kabuklu Meyveler Sempozyumu, 212-225, 10-11 Ocak, Samsun.

Beyhan, M.A., Yıldız, T., 1996. Fındık ve diğer sert kabuklu meyvelerde uygulanan mekanik hasat yöntemleri. Ondokuz Mayıs Üniversitesi Ziraat Fakültesi, Fındık ve Diğer Sert Kabuklu Meyveler Sempozyumu, 185-194, 1011 Ocak, Samsun.

Bora, G., Ehsani, R., Hebel, M., Lee, K., 2007. In-situ measurement of the detachment force of individual oranges harvested by a canopy shaker harvesting machine. Prc. Fla. State Hort. Soc., 120: 38-40.

Civil, C., 2009. Eğirdir Bölgesi'nde yetiştirilen bazı erik çeşitlerinde mekanik hasat parametrelerinin belirlenmesi. Yüksek Lisans Tezi, Selçuk Üniversitesi Fen Bil. Enst., Tarım Makinaları Anabilim Dalı, Konya.

Demir, T., 2004. Türk findık çeşitlerinin rapd markörleri ve pomolojik özellikleri ile tanımlanarak çeşitler arasındaki akrabalık ilişkilerinin belirlenmesi, Doktora Tezi, Ondokuz Mayıs Üniversitesi Fen Bil. Enst., Bahçe Bitkileri Anabilim Dalı, Samsun.

Erdoğan, D., 1988. Ağaç meyvelerinin makine ile hasadında uygulanan ilkeler. Tarım Makinaları Bilimi ve Tekniği Dergisi 2: 19-23.

Erdoğan, D., 1990. Meyvelerin makine ile hasadında önemli parametreler. Tarım Makinaları Bilimi ve Tekniği Dergisi, 2: $17-20$.

Farinelli, D., Tombesi, S., Famiani, F., Tombesi, A., 2012. The fruit detachment force/fruit weight ratio can be used to predict the harvesting yield and the efficiency of trunk shakers on mechanical olive harvesting. I. International Symposium on Mechanical Harvesting and Handling Systems of Fruits and Nuts. Acta Hort., 965: 61-64. 
Gezer, İ., 1999. Determination of relationships between spring rigidity and some other tree properties in apricot trees with respect to harvesting technique (In Turkish). Turkish Journal of Agriculture and Forestry, 23: 1065-1069.

Keçecioğlu, G., 1975. Atalet kuvvet tipli sarsıcı ile zeytin hasadı imkânları üzerinde bir araştırma. Ege Üniversitesi Ziraat Fakültesi Yayınları, No: 288, Bornova-İzmir, Türkiye.

Khorsandi, F., Loghavi, M., Kamgar, S., 2012. The effects of shaking frequency and amplitude on the detachment of estahban dried fig (Ficus carica cv. Sabz). Iran Agric. Res., 31(1): 49-62.

KİBGS, 2008. Karadeniz İhracatçı Birlikleri Genel Sekreterliği Kayıtları. Giresun, Türkiye.

Kouraba, K., Gil-Ribes, J.A., Blanco-Róldan, G.L., JaimeRevuelta, M.A., Barranco-Navero, D., 2004. Suitability of olive varieties for mechanical harvester shaking. Olivae, 101: 39-43.

Loghavi, M., Abounajmi, M., 2001. Effects of shaking mode, frequency and amplitude on 'Shahani'date fruit detachment. I: Design and development of an experimental shaker. Iran Agric. Res., 20(2): 121-138.

Mailer, R., Conlan, D., Ayton, J., 2005. Harvest timing for optimal olive oil quality. A report for the Rural Industries Research and Development Corporation. Australian Government, Rural Industries Research and Development Corporation, Australia.

Polat, R., 1999. Antep fistığının mekanik hasat olanakları ve mekanizasyonuna yönelik özelliklerin belirlenmesi üzerine bir araştırma. PhD, Trakya Üniversitesi Fen Bil. Enst., Tarım Makineleri Anabilim Dalı (Basılmamış), Edirne, Türkiye.

Polat, R., Acar, I., Cem Bilim, H. I., Saglam, R., Bekir Erol, A.K., 2011. Determination of spring rigidity and fruit detachment force with respect to harvesting technique in pistachio nut trees African Journal of Agricultural Research, AJAR, 6(3): 532-537.

Polat, R., Ülger, P., Sağlam, C., Açar, İ., 2006. Determination of spring rigidity and fruit detachment force with respect to harvesting technique in plum trees. J. Agric. Machinery Sci., 2(4): 329-335.

Pozo, L., Malladi, A., John-Karuppiah J.J., Lluch, Y., Alferez, F., Burns, J.K., 2007. Daily fluctation in fruit detachment force of 'Valencia' orange is related to time of day, temperature, relative humidity, fruit weight and juice pecentage. Proc. Fla. State Hort. Soc., 120: 41-44.
Rabcewicz, J., Danek, J., 2010. Evaluation of mechanical harvest quality of primocane raspberries. J. Fruit Ornam. Plant Res., 18(2): 239-248.

Safdari, A., Ghassemzadeh, H.R., Abdollahpour S.H.A., Ghafari, H., 2010. Design, construction and evaluation of a portable limb shaker for almond tree Australian Journal of Agricultural Engineering, AJAE, 1(5): 179-183.

Segovia-Bravo, K.A., García-García, P., López-López, A., Garrido-Fernández, A., 2011. Effect of bruising on respiration, superficial color, and phenolic changes in fresh manzanilla olives (Olea Europaea pomiformis): development of treatments to mitigate browning, J. Agr. Food Chem., 59(10): 5456-5464.

Tekgüler, A., Yıldız, T., Sauk, H., 2015. Determination of spring rigidity and fruit detachment force in Yomra variety hazelnut trees. Agricultural Mechanization in Asia, Africa and Latin America, 46(2) :13-16.

Torregrosa, A., Albert, F., Aleixos, N., Ortiz, C., Blasco, J., 2014. Analysis of the detachment of citrus fruits by vibration using artificial vision. Biosystems Engineering, 119: $1-12$.

TUIK, 2014. Turkish Statistical Institute. Available from URL: http://www.tuik.gov.tr/

Villibor, G.P., Santos, F.L., Marçal de Queiroz, D., KhouryJunior, J.K., Francisco de Assis de Carvalho Pinto, 2016. Determination of modal properties of the coffee fruit-stem system using high speed digital video and digital image processing Acta Scientiarum. Technology Maringá, 38(1): 41-48.

Yıldız, T., 2000. Traktörle çalıştırılabilir-yerden toplama üniteli bir fındık hasat makinesinin tasarımı. PhD, Ankara Üniversitesi Fen Bil. Enst., Tarım Makineleri Anabilim Dalı (Basılmamış), Ankara, Türkiye.

Yıldız, T., Tekgüler, A., 2014. The effects of different maturity times of fruit ripening and limb connection heights on the percentages of fruit removal in mechanical harvesting of hazelnut (cv. Yomra). Tarım Bilimleri Dergisi-Journal of Agricultural Sciences, 20: 38-47.

Yousefi, Z., Gholiyan, A., 2013. A study of olive harvesting methods in Iran from an economic perspective. Tech $\mathbf{J}$ Engin. App Sci., 3(12): 1005-1015. 